\title{
CHRISTIAN THEOLOGICAL INTERPRETATIONS OF GOD'S GRACE IN THE BINDING OF ISAAC
}

\author{
CAREY ELLEN WALSH* \\ Villanova University, Pennsylvania
}

\begin{abstract}
Typological exegesis, practiced by the early church fathers, enables us to catch spiritual meanings in the promise to Abraham, namely, that through him "all the nations of the earth be blessed" (Genesis 22:18). Christian interpreters caught a divine truth when they discerned an ecclesial meaning. God had just revealed to Abraham that he was not alone, that a church was in the future. His typological interpretation accounts for the seeming repetition of the promise in Scripture: it contains new revelation. The promise to Abraham has always involved a multitude of descendants through Isaac. But after his near sacrifice as a Christ figure, the multitude is the church which emerged after Christ's death and resurrection.
\end{abstract}

KEY WORDS: "Binding of Isaac", typology, righteousness, "sacrifice of Isaac", atonement, Abraham, Moriah

\section{Introduction}

From its beginnings in the New Testament the Christian interpretation of Genesis 22 saw connections between the near sacrifice of Isaac and the crucifixion of Christ. It focused on the element of sacrifice in the tale while Jewish interpreters tended to focus on the relationships between God, Abraham, and Isaac. The other elements of the story also typical in Jewish interpretation, e.g., the conversation between father and son, the location of the sacrifice, the knowingness of Isaac, etc., by comparison receive scant attention in Christian interpretation.

The term Aqedah-the binding of Isaac-is typical of Jewish, but not Christian interpreters, who focus primarily on the spiritual meanings of the

* CAREY ELLEN WALSH, ThD (Harvard) is associate professor of Old Testament at Villanova University.

(C) EMANUEL UNIVERSITY of ORADEA

PERICHORESIS $10.1(2012)$ 
divine command to sacrifice. ${ }^{1}$ Therefore, I will refer to the story of Genesis 22 throughout this essay as "Abraham's offering". Ironically, for Christian interpreters the horror in the tale, of a father offering his son, is diffused by its later actually happening in the gospels. Origen, for instance, notes a comparison between Abraham and the God of Jesus Christ. Both are willing to offer their sons in a "magnificent generosity" whereby Abraham offers a mortal son not put to death, and God delivers the immortal son to death. ${ }^{2}$ In one story the sacrifice of the son is averted, though the horror at what nearly happened lingers. In the second story, there is no reprieve. The sacrifice of the son occurs, and its horror is recalibrated as the gift of grace in atonement. Christ is sacrificed, but effects a divine forgiveness for all. The horror, it would seem, was worth it for the soteriological gain it wrought. ${ }^{3}$ One live son is saved by the substitution of a ram. The other, dead son becomes saved and saving through substitutionary atonement. As Luther remarked, interpretation of this difficult story must rely, not on reason, but on the Word, "namely, that he who is dead lives, and he who lives, dies".

The earliest Christian interpreters sought to understand Jesus by reading their scriptures, what was later termed the Old Testament. This led to a general shift in attention from the Torah, the first five books of the Bible, which is central for Jewish interpreters to the Prophets. ${ }^{5}$ Christian Bibles positioned the prophetic corpus in the last part of the Old Testament before the New in order to point the way to Christ, while the sequence of the material in Jewish Bibles remains Torah, Prophets, and Writings. Also, the Christian shift in perspective meant that the Torah tended to be read as

1 Claus Westermann, Genesis 12-36. A Commentary, trans. John J. Scullion (Minneapolis, MN: Augsburg, 1985), 354.

2 Mark Sheridan (ed.), "Genesis 12-50", vol. 2, Ancient Christian Commentary on Scripture. Old Testament (Downers Grove, IL: IVP Academic, 2002), 108.

3 The gospels themselves, especially Mark, wrestle with the violence of crucifixion. Modern theology revisits the violence grounding atonement notions. See Stephen Finlan, Problems with Atonement. The Origins of, and Controversy about, the Atonement Doctrine (Collegeville, MN: Liturgical, 2005); Gil Bailie, Violence Unveiled. Humanity at the Crossroads (New York, NY: Crossroads, 1997); Regina M. Schwartz, The Curse of Cain. The Violent Legacy of Monotheism (Chicago, IL: University of Chicago Press, 1997); and especially, Jürgen Moltmann, The Crucified God. The Cross of Christ As the Foundation and Criticism of Christian Theology (Minneapolis, MN: Fortress, 1993).

4 Martin Luther, Luther's Works, ed. by Jaroslav Pelikan, vol. 4 (St Louis, MO: Concordia, 1964), 113.

5 P. R. Ackroyd, P. R., and C. F. Evans, eds., The Cambridge History of the Bible. From the Beginnings to Jerome (Cambridge: Cambridge University Press, 1970), 413.

PERICHORESIS 10.1 (2012) 
prophetic, that is, as prefiguring Jesus. It is important to note that at the time of Christianity's spread in a Greco-Roman world, texts were viewed as oracular, i.e., as containing hidden divine messages. ${ }^{6}$ The earliest followers of Jesus did not understand why their rabbi had been executed and so they turned to their scriptures for illumination of God's meaning. The earliest beliefs about Jesus included that his death and resurrection happened "according to scriptures" and so it was natural that they looked into them with new eyes. ${ }^{7}$ Genesis 22, along with the stories of the Passover lamb (Exodus 12), ${ }^{8}$ the scapegoat (Leviticus 16), ${ }^{9}$ and the suffering servant songs (Isaiah 42:1-4; 49:1-6; 50:4-9; and 52:13-53:12) particularly aided in their understanding of Christ's sacrificial death. ${ }^{10}$

In the history of Christian interpretation of Genesis 22, the connection between Isaac and Christ is positive and illuminating of God's mission. Abraham is seen as an exemplar of faith. And throughout Christian tradition, interpreters follow Origen's lead on the legitimacy of interpreting scripture by means of scripture, i.e., drawing connections between texts in the Bible. ${ }^{11}$ From the Enlightenment on, though, biblical interpreters focus not on connections between texts and the two Testaments but on discrete stories, and in this case, on the troubling aspects in the divine command itself. Immanuel Kant, for example, could not reconcile a command to kill one's son with a universal moral duty within us. The contradiction cannot go away, and so he professed uncertainty about it being God's voice that had issued the command. ${ }^{12}$ From Julius Wellhausen (1844-1914) on, with the rise of historical criticism, interpreters have been concerned with the origin of the story. There is widespread scholarly agreement that it is an etiology, that is, an explanation of a cultural fact, detailing the abolition of human sacrifice by substituting an animal. In this view, then the story helps to name a cultic site, Mt. Moriah, important at the time of the author(s). ${ }^{13}$

6 Ackroyd and Evans, Cambridge History of the Bible, 454.

7 G. W. H. Lampe (ed.), The Cambridge History of the Bible. The West from the Fathers to the Reformation (Cambridge: Cambridge University Press, 1969), 156.

81 Corinthians 5:7; John 1:29, 36; Revelations 6:1; 14:4; 17:14.

9 Finlan, Problems with Atonement, 21; Barnabus 7.7; Galatians 3:13; 2 Corinthians 5:21; Romans 3:25; 6:6; 7:4; 8:3.

10 Shalom Spiegel, The Last Trial, trans. Judah Goldin (New York, NY: Random House, 1967), 83-84.

11 Sheridan, "Genesis 12-50", 111.

12 Westermann, “Genesis 12-36”, 354.

13 Hermann Gunkel, Genesis, trans. Mark E. Biddle (Macon, GA: Mercer University Press, 1997), 233-40; Jon D. Levenson, The Death and Resurrection of the Beloved Son. The Trans- 
Let us turn now to Christian traditional interpretation of Abraham's offering, which begins as early as the New Testament.

Scripture on Abraham's Offering

By faith Abraham, when put to the test, offered up Isaac, and he who had received the promises was ready to offer his only son, of whom it was said, "Through Isaac descendants shall bear your name". He reasoned that God was able to raise even from the dead, and he received Isaac back as a symbol. (Hebrews 11:17-19)

There are two interpretations of the tale of Abraham's offering in the New Testament: first, in this passage, Hebrews 11:17-19; and second, in James 2:21. It is never mentioned by Jesus or any of the Gospels. The Hebrews passage is part of a list of acts of faith of the patriarchs and other significant figures in the Old Testament, e.g., Abel, Noah, Moses, Gideon. And, of all the acts in which Abraham demonstrated his faith, it is his willingness to sacrifice his son that is recalled in Hebrews.

The primary significance of the story for the author of Hebrews lies, then, in Abraham's unwavering demonstration of faith in his God. ${ }^{14} \mathrm{He}-$ brews 11 , it shall be recalled, makes the difficult, true claim that "faith is the realization of what is hoped for and evidence of things not seen" (Hebrews 11:1), and Abraham's willingness to sacrifice his own son testifies to such faith. The contradiction between God's promise of many descendents through this very son and God's command to sacrifice the same son must have been acute for the patriarch. Abraham, for the author of Hebrews, negotiates that contradiction by listening to something unseen, unknown, namely, that somehow the painful contradiction is illusion. The notion of resurrection is precisely that "evidence unseen" and so for Hebrews, Abraham is theologically light years ahead of his time. He has faith in a belief that is revealed only with the resurrection of Christ. Luther agrees with the author of Hebrews that Abraham's belief in resurrection is what enables him pass the test. ${ }^{15}$ Nowhere in the Old Testament is belief in resurrection evi-

formation of Child Sacrifice in Judaism and Christianity (New Haven, CT: Yale University Press, 1993), 112-14.

14 The consensus of modern biblical scholarship is that Hebrews was written not by Paul, as tradition has long claimed, but rather another, anonymous author. Luke Timothy Johnson, The Writings of the New Testament. An Interpretation (Minneapolis, MN: Fortress, 1999), 458-61.

15 Luther's Works, vol. 4, 96.

PERICHORESIS 10.1 (2012) 
dent, with the exception of Daniel 12:2, a relatively late text, written sometime in the 2nd century BC. ${ }^{16}$

So, it is Abraham's preternatural faith that emboldens him to obey God's command. The invisible- -evidence unseen"- takes precedence over the seen, viz., his own son. Abraham's faith in this unknown, later doctrine is then affirmed when he received Isaac back "as a symbol" (Hebrews 11:19). The Greek here, parabole, "symbol", from which the English "parable" is derived, is helpful for it signifies something unseen. Isaac, as parabole, is more than a spared son. He now symbolizes the unseen truth of resurrection. ${ }^{17}$ The spared son symbolizes that something new is afoot in the divine sphere, which is Christ. Abraham does not merely pass God's test, and get his son Isaac back; he gets a glimpse of New Testament truth, namely, that someday even the death imperiling his son will have no sting (1 Corinthians 15:55).

Things then do not return to normal after Abraham's test. They are brand new. The threat of Isaac's death is not suppressed or ignored in Hebrews 11. It is simply surpassed with a greater truth, that of resurrection. Abraham and Isaac are not wounded by their harrowing ordeal. For the author of Hebrews, they come away unscathed and rejuvenated, with Isaac the enduring "symbol" that death is not the end (verse 19). In fact Luther stresses that they both come away giddy with victory, a victory over death; Isaac's physical death yes, but also the dread with which death grips mortals. As a result of their obedience, Abraham and Isaac witness, Luther maintains, a divine truth, that death is mere sport for God. ${ }^{18}$ As a result, they walk away existentially freer than their contemporaries.

The saving of Isaac prefigures the resurrected Christ. The connection of Isaac with Christ will shape all subsequent Christian interpretations of Abraham's offering, as we shall see. In fact, the King James translation makes the connection even more explicit with the phrase "his only begotten son" (verse 17), while the New American Bible (NAB) translation has "only son". Here the Kings James is closer to the Greek original, "monogene",

Ezekiel's tale of dry bones 37:1-13 is metaphor for the restoration of Israel after its tragic exile. Elisha revive a dead boy (1 Kings 4:18-37), much as Jesus revived Lazarus, but these stories denote revivification, not resurrection. The difference is that Israel, the boy, and Lazarus, though revived, will eventually die (John 11:1-44).

17 Romans 6:5, 8:17.

18 Luther Works, vol. 4, 117. 
"only born" of Hebrews 11, while the NAB is closer to the Hebrew 'echad of Genesis 22:1: "only one". ${ }^{19}$

Jesus himself does not mention the story of Abraham's offering explicitly though he speaks of Abraham on numerous occasions. When he teaches about everlasting life as always having been God's plan, he asserts that the God of the fathers, of Abraham, Isaac, and Jacob, is a God of the living. Jesus is telling the stunned crowd that Abraham and Isaac (and Jacob) are still alive. He may or may not be alluding to the story of Abraham's offering, but he does relate the idea of resurrection with Isaac explicitly (Matthew 22:32; Luke 20:37). Luther follows this logic and is assured that all the patriarchs, Abraham, Isaac, and Jacob who placed their hope in God believed in the resurrection of the dead..$^{20}$

Abraham's demonstration of faith is echoed in the Pauline letters, even though the Genesis 22 story is not explicitly recalled. For Paul, Abraham is clearly the father of faith because he believed and obeyed God (Genesis 15:6) long before the covenant of circumcision was enacted (Genesis 17:10). The sequence is crucial for Paul's theology and mission to the Gentiles. Abraham becomes the example of faith in God before the law (e.g., circumcision), and so validates the inclusion of faith-filled Gentiles to God's saving mission alongside the faith-filled and law-abiding Jews. Christians are part of God's promise through Isaac. ${ }^{21}$ Abraham is the linchpin for universal salvation in Christ and for Paul it rests on the patriarch's faith.

The relation between faith-believing that God was in Christ-and works-obeying God's commandments—is an ongoing dispute in the New Testament. For Paul, faith is paramount. For James, works also matter. James uses the example of Abraham, this time specifically with the offering of Isaac, in nearly the opposite sense from Paul. Abraham is celebrated not for faith, but for his works in the ordeal: "Was not Abraham our father justified by works, when he offered his son Isaac upon the altar?" (Jasmine 2:21). James credits Abraham's active obedience to the divine command as his works.

The Septuagint, the Greek translation of the Old Testament, has "loved son, whom you love" twice using the verb agape, "(selfless) love".

Luther's Works, vol. 7, 116.

Romans 9:7-8; Galatians 3:16, 18; Galatians 4:22-24, 28.

PERICHORESIS 10.1 (2012) 
John Calvin takes a different tack in understanding the passage in James. ${ }^{22}$ He states that this work of Abraham in Genesis 22 did not win Abraham righteousness with God because God had earlier credited him with it in Genesis 15:6. Calvin argues that "it is absurd for the effect to precede the cause", and Abraham was justified long before even Ishmael, the older brother, was conceived. Therefore, Calvin points out, the verse in James expresses the declaration, not the imputation of righteousness, as that had already occurred long before. ${ }^{23}$ Calvin returns to Genesis 22 to discuss the divine promise made after the ordeal, in verses 16-18. There it appears that Abraham is rewarded with a promise of descendents and blessing, etc, but this, Calvin correctly notes, is simply a repetition of the promise Abraham has already received. God is indeed generous here as "He will repay to works what He had freely given before the works". ${ }^{24}$

The interpretive strategy of both Paul and the author of Hebrews is typological. This method examines Old Testament figures and events as prefiguring or foreshadowing figures and events in the New. ${ }^{25}$ Typology, from the Greek, typos, meaning "stamp" notes an impression in a text, a meaning not apparent before New Testament times. Christians believe revelation occurs in the Old and New Testaments and in their juxtaposition. Gospel events recapitulate the saving acts of God in the Old Testament. ${ }^{26}$ The Second Vatican Council (1962-65) confirms this view in its Dogmatic Constitution on Divine Revelation, drawing on a quotation by Augustine: "God, the inspirer and author of both Testaments, wisely arranged that the New Testament be hidden in the Old and the Old be made manifest in the New". ${ }^{27}$

Typology differs from allegory in important ways. An allegory has an abstract concept attached to a concrete image in a text. The abstraction is privileged over the concrete image. Allegory assumes a hidden meaning that is more important than the literal sense. Typology, also assumes a hidden

The Protestant reformers tended to align themselves with Paul on the faith side of the faith and works dispute in reaction to what they saw as the works-based sacramental system of the Catholic Church.

John Calvin, Institutes of the Christian Religion, trans. Henry Beveridge (Grand Rapids, MI: Eerdmans, 1953), 370.

Calvin, Institutes, 375-76.

Ackroyd and Evans, Cambridge History of the Bible, 413.

Lampe, Cambridge History of the Bible, 157.

"Dogmatic Constitution on Divine Revelation”, n.16, ed. by Austin Flannery, O. P., Vatican Council II, vol. 1: The Conciliar and Postconciliar Documents (Northport, NY: Costello, 1975), 750-65. 
meaning, but one that comes to light in consort with the New Testament. In typology, both concrete and hidden meanings remain important. In fact, typology insists on a revelatory connection between two events. In this instance, Genesis 22 does not contain Christ's crucifixion in some sort of Bible code that cruelly leaves its intended original audience in the dark. Rather, the text is polyvalent, full of meanings always, and additional theological resonances become clear after the crucifixion.

In allegorical interpretation, only the abstract idea, say of faith or obedience, matters. The rest are incidentals. Modern biblical criticism tends to confuse these two strategies of interpretation and reject them both as "reading into" (eisegeting) a biblical text meanings that were likely not there for the original authors. ${ }^{28}$ Modern study aims to "draw out" (exegete) meanings that the authors likely intended. Recall that for modern people the Bible is to be read and studied. For the early Christians it was oracular and also written somehow with the guidance of the Holy Spirit. ${ }^{29}$ Jesus himself used typology when he told the story of his death and resurrection by drawing on the story of Jonah in the belly of the big fish for three days (Matthew 12:38-42; Luke 11:29-32). His is typological interpretation because it reveals a connection between events; the details of the Jonah story matter alongside what they portend of Jesus' death. Typological interpretation was long viewed as legitimate in Christian tradition because it had apostolic beginnings with Christ and Paul. ${ }^{30}$ Let us turn now to how Christians have interpreted the specific details in the story of Abraham's offering.

\section{“God tested Abraham" (verse 1)}

The first thing to note is that the story differs from other Abraham narratives by stating its theme at the front: God tested Abraham. ${ }^{31}$ For Origen,

Allegorical, not typological, interpretation would tend to rob texts of any serious historical meaning. Ackroyd and Evans, Cambridge History of the Bible, 379. For an excellent discussion of early interpretive methods, see David C. Steinmetz, "The Superiority of Pre-Critical Exegesis", Theology Today 37 (1980): 27-38.

29 Ackroyd and Evans, Cambridge History of the Bible, 461, 474.

30 Ackroyd and Evans, Cambridge History of the Bible, 466.

31 Westermann, "Genesis 12-36", 354-55. Westermann argues that the story conforms to a threefold test narrative structure: 1). lay the task on the protagonist; 2). the protagonist carries out the task; 3). the protagonist discovers whether or not he has passed the test. Jon Levenson insists that verse 1 is not a theme, adding that it is typically only Christian interpreters who see one theme in the story. The Death and Resurrection of the Beloved Son, 125-126.

PERICHORESIS $10.1(2012)$ 
this is the only reason for the divine command and Abraham passes the test, because as Hebrews 11:17 shows, he did not hesitate: "Abraham ... was ready to offer his only son" ${ }^{32}$ For Luther, the command drastically affects Abraham for the rest of the chapter. After God's command, he notes, Abraham can "see nothing else. Everything fades out in him". ${ }^{33}$

The central theological question of the passage becomes why God would need a test of Abraham at this point. And here the interpreters readily protect God's omniscience. The test is never because God does not know what Abraham will do, but for others reasons. St. Thomas Aquinas, as was his wont, dissects the issue into various parts. There are, he reasons, two kinds of tests, those that lead to some good, and those from the devil that deceive and trick people. Aquinas rules out the possibility that this could somehow be a test from the devil. Further, Aquinas asserts, the good can be for Abraham's sake or for the sake of others. Aquinas deliberates that the test in Genesis 22 is obviously for the good, and for the sake of others, not Abraham. The patriarch's example of faith, which triumphs over the testing of "fleshly concerns", i.e., that he would love his son, helps Christians in their own struggles. "For if concupiscence triumphs", Aquinas warns, "the person does not love God in a perfect manner, nor does he love in a perfect manner when the concerns of the world either frighten him or exert an undue influence upon him". ${ }^{34}$

Luther understands the testing of Abraham to be an opportunity for readers to see that "good fruits come from a good tree", viz., Abraham. ${ }^{35} \mathrm{He}$ highlights the aspect of contradiction in the test. Isaac is the son of all of God's promises to Abraham and he is the one whom Abraham must sacrifice. God throws Abraham into a kind of theological Catch-22 that must have vexed him sorely. The verb for "test" (Hebrew: nasah) means both "test" and "tempt", and so Abraham would likely have been weighing what to do. ${ }^{36}$ To Abraham, God was a best friend, and not an enemy or tyrant. Hence this test from God, Luther argues, must have brought on an internal

Sheridan, "Genesis 12-50", 102

Luther Works, vol. 4, 109.

St. Thomas Aquinas, "Commentary on St. Paul's Epistle to the Thessalonians", in The Collected Works of St. Thomas Aquinas (Electronic edition, InteLex Corporation, 1993), 24.

Martin Luther, "Sermon on the Eleventh Sunday after Trinity: A Picture and an Example of a True Saint and a Real Hypocrite”, vol. 4, Sermons of Martin Luther (Electronic edition, Intelex Corporation, 1995), 341.

Luther Works, vol. 4, 91.

PERICHORESIS 10.1 (2012) 
struggle within Abraham and doubts about whether or not he had displeased God at some point. In fact, Luther adds, Abraham's ordeal was harsher than Mary's when she lost her son, Jesus, in Jerusalem (Luke 2:4150 ), because at least she would know that he was alive. ${ }^{37}$

\section{"Go to the land of Moriah" (verse 2)}

Jewish interpreters discuss the location of the divine test, Mt. Moriah, in considerable detail. This is understandable since Mt. Moriah is traditionally considered to be the location where Solomon's temple was later built (2 Chronicles 3:1). St. Jerome concurs with Jewish interpreters here, based on his personal experiences traveling from Hebron to Jerusalem. ${ }^{38}$ Verse 14 states that it occurred at "the mount of the LORD", which biblical tradition locates in Jerusalem (2 Chronicles 3:1; Psalm 24:3; Isaiah 2:3, 30:29; and Zechariah 8:3).

Jewish interpreters tend to derive the place name, Moriah, from the verb "fear" or "awe", yira', because this term suggests a stance for worship. Jerome uses instead the similar, "see", ra'ah and understands "Moriah" as a causative, "cause to see" meaning "enlightening" place. From there, he argues, God's oracle ${ }^{39}$ came forth, first in law and then with the Holy Spirit. ${ }^{40}$ Both verbs are later used in the story. In verse 12: "You fear God"; and in verse 14, when Moriah is named as the place where God "will be seen", "as it is said to this day", suggesting a site of continuing worship. In this view, for Judaism, the story of Abraham's offering in Genesis 22 provides the theological foundation for the temple. ${ }^{41}$

Most Christian interpreters also presume that Mt. Moriah is in Jerusalem. Caesarius of Arles states outright that the place of Isaac's sacrifice is where Jesus is later crucified.$^{42}$ Hence, even the story's very geography is typologically forecasting the future execution of Christ. Luther, however

37 Luther Works, vol. 4, 94.

38 He adds that Abraham must have been living in Gerar, rather than the Oaks of Mamre at the time, to account for a three day journey. Luther too ponders the journey's length and posits that the distance from Mt. Moriah to left behind servants to be about a quarter of a mile. Luther Works, vol. 4, 109.

39 The Hebrew term for the Holy of Holies, debir, shares the same root with the word for "word", dabar.

40 Jerome, Saint Jerome's Hebrew Questions on Genesis, C. T. R. Howard, trans. (Oxford: Clarendon, 1995), 55.

41 Levenson, Death and Resurrection, 115.

42 Sheridan, "Genesis 12-50", 111.

PERICHORESIS 10.1 (2012) 
does not think Mount Moriah is in Jerusalem because the entire region around the city is mountainous and it would not, then, have been possible for Abraham to see it from afar (verse 4).

After the ordeal, Abraham names the site "The Lord will see' as it is said to this day, "On the Mount of the Lord it shall be seen" (verse 14). Luther confirms that grammatically the latter phrase is passive, "The Lord shall be seen". But he adds that theologically, the active sense, "The Lord will see" is also correct since God "saw to it" that a ram would be there. ${ }^{43}$ Jerome picks up on the phrase "as it is said to this day". He comments further that the "Lord sees" is a saying for the Jews of his time when they are in distress. They use the phrase in troubled times for consolation in the belief that God will see or care, just as he did in the story of Abraham's offering. "To this day", when the ram's horn is sounded at the Jewish celebration of the New Year, it commemorates the substituted ram in this story and is thought to invoke God's mercy. ${ }^{44}$

\section{The Sacrifice of the Son}

It was noted above that Christian interpreters view the near sacrifice of Isaac as prefiguring Christ's crucifixion. ${ }^{45}$ Barnabas is explicit that the sacrifice of Isaac is a foreshadowing of Christ's passion. ${ }^{46}$ Augustine writes of Isaac,

... the prefiguration was not achieved without bloodshed, in the one case by the slaying of a ram,... In this way the resurrection was symbolized, but the reality of it was reserved for our true Lord. ${ }^{47}$

Even the poignant detail of verse 6 that "Abraham took the wood of the burnt offering and laid it on Isaac" reminds interpreters like Origen of Christ having carried his own cross on the via dolorosa. For Clement of Alex-

Luther Works, vol. 7, 138-39.

Shalom Spiegel, The Last Trial, 92.

Caesarius of Arles, FC 47:16; Augustine, "Exposition of Psalm 51", Expositions of the Psalms, 51-72, III/17, 341.

"Barnabas 7:3"; Sheridan, "Genesis 12-50", 90.

Augustine, "Exposition of Psalm 51 Verses 1-2. The Hidden Meaning of the Title", Expositions of the Psalms, 51-72, III/17, The Works of Saint Augustine (3rd release), electronic edition, 17. 
andria Isaac is a type for Christ in numerous aspects: carrying his own wood, being the son, and being the intended victim. ${ }^{48}$

Augustine examines what lesson the sacrifice of a son could hold. Augustine's exposition shows his typological interpretation in action. Thus he defines the hard lesson:

In a word, not to value above God what God gives us. We are still dealing only with the literal meaning of what was done, before we come to the inner secret of the thing signified, that is to what lies hidden in this mystery or sacrament of Abraham being ordered to kill his only son. And when he wants to take it away from you, don't let him go down in your estimation, because God is to be loved free, you get from God than God himself? Sermon $2^{49}$

Augustine distinguishes between the literal meaning of a biblical text and its signified "inner secret", the symbol. But he insists that both meanings retain their importance in Christian interpretation. Isaac never becomes merely an allegory for our instruction. Augustine maintains that Isaac "really was born to Abraham, and that he also represented something else. The same is true about his obeying God when ordered to sacrifice his son".

History and symbol are always held in tandem in Augustine's exegesis. For him, it is not the words of the biblical text that assume primary importance, but rather the doctrine they are expressing. ${ }^{50}$ This emboldens him to interpret a lesson that is there for all. For Augustine, more so than for other patristic interpreters such as Origen, the history in biblical stories remains significant because it is the domain of divine-human interaction. His is a fully realized incarnational view of history. God entered history in the person of Jesus and so the details will always matter. Divine history, for Augustine, is evident in the Bible in a twofold way. It is a record of res gesta —action in God's past and another element, res gestura—of what God will do. ${ }^{51}$ “Genesis 12-50”, 104-05.

49 Augustine, Sermon 2, "Abraham, Tested by God", Sermons (1-19) on the Old Testament. III/1. The Works of Saint Augustine (3rd release), electronic edition, 178.

$50 \quad$ Ackroyd and Evans, Cambridge History of the Bible, 574.

51 Ackroyd and Evans, Cambridge History of the Bible, 553.

PERICHORESIS 10.1 (2012) 
A Three Day Journey

A significant difference between Jewish and Christian interpreters occurs with verses 3-4. At issue is how the phrase "on the third day" should be understood.

...he arose and went to the place of which God had told him. On the third day Abraham lifted up his eyes and saw the place afar off. verses 3-4

Grammatically in Hebrew, there are no periods to end sentences, and so the phrase "on the third day" could go with either sentence in verses $3-4 .^{52}$ The interpretive question becomes, did Abraham leave on his journey after three days of preparation, saddling the donkey, gathering his servants, cutting wood, etc? Or, did he complete the journey on the third day? Did he set out or arrive "on the third day"? Christian interpreters stress that Abraham arrived on the third day as a typology of the resurrection and even the trinity. ${ }^{53}$ In verse 3 "Abraham rose early in the morning" after having heard God's command in verse 2. Luther applauds the patriarch's eagerness to obey. ${ }^{54}$ This detail in verse 3 shows that Abraham did not delay and supports the interpretation that he arrived rather than set off "on the third day".

Origen considers the general duration of the journey to be spiritually significant. Such a long amount of time allows Abraham rigorous contemplation of his life, Isaac's, and the impending sacrifice, and this too is all part of God's testing. Origen and Luther both stress that a journey of three days, the whole time knowing the nature of the command, becomes a test of emotional endurance for Abraham. Luther and Calvin argue that Abraham suffered three days of fatherly torment and the "darts of Satan" that are misgiving, doubt, and second-guessing. ${ }^{55}$ Calvin is clear that the death of a child under any circumstance would be terrible. A fatal sickness or murder by another is one thing, he notes, but Abraham journeys with the awful foreknowledge that his son will die by his own hand. ${ }^{56}$ Abraham, Origen surmises, would struggle between "affection and faith, love of God and love es is quite late, occurring sometime in the late Middle Ages.

53 St. Jerome's Hebrew Questions, 178-79. For Caesarius of Arles the three days to the sacrifice also brings to mind the trinity. Sheridan, "Genesis 12-50", 103.

Luther Works, vol. 4, 99.

Luther Works, vol. 4, 110.

Calvin, Institutes, 392.

PERICHORESIS 10.1 (2012) 
of the flesh". ${ }^{57}$ In addition, the hike includes an ascent, up a mountain. Since Abraham's offering occurs above the surrounding highlands, Origen argues, the movement upwards symbolically shows the patriarch exalted by faith. Abraham, he states, becomes a model for all Christian pilgrims as he "abandoned earthly things and ascended to things above". ${ }^{58}$ Luther champions Abraham as a model of fortitude too since it is a wonder he did not die of grief at any point during the three long days. ${ }^{59}$

\section{Narrative Action}

The next issue dealt with by Christian interpreters is not limited to specific verses but involves all of the actions in the scene. Abraham is the subject of many verbs and engages in mundane tasks such as saddling his donkey that presumably servants would do. The details of his active participation, then, also testify to the patriarch's obedience. He "rose" early, "saddled" his donkey, "took" two servants, "cut" the wood, and "hiked" up to Mt. Moriah (verse 3), "took" the wood, "laid" it on Isaac, "carried" the fire and knife (verses 6-7), "built" an altar, "arranged" the wood, "bound" his son, "placed" him on the wood (verse 9), "reached" out and "grabbed" the knife (verse 10). It is quite clear from this litany of verbs that Abraham is active and willing, rather than begrudging in his obedience. He is not simply going through with God's command. He is performing it meticulously. With all of the patriarch's activity described, Cyril of Alexandria imagines how difficult the job of a painter would have been in depicting this story since he would have to produce so many paintings ${ }^{60}$ The careful description of all of Abraham's actions enhances the taut, dramatic tension in the story.

Luther asserts that all of these verbs truly testify to Abraham's "extraordinary obedience" because Abraham has 318 servants (Genesis 14:14) who would otherwise likely perform these tasks ${ }^{61}$ Origen additionally credits Isaac with willing obedience because he walks side by side with Abraham, rather than behind him: "the two of them went together" (verse 6). Luther, though, disagrees and claims instead that even though Isaac is old enough to carry a donkey's load worth of wood, i.e., a grown man, Isaac does not

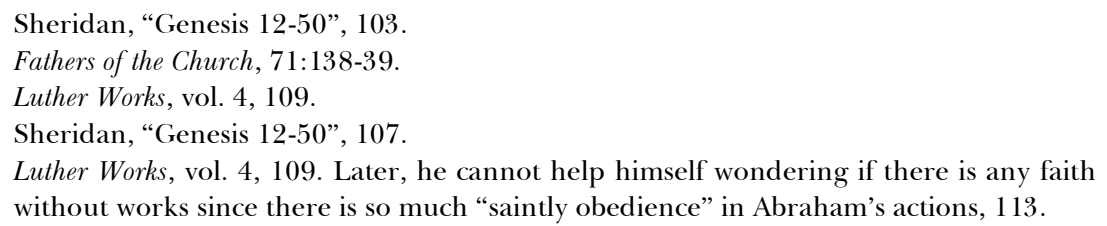


know he is to be killed upon it. ${ }^{62}$ This detail of walking together, a united front, is important for Origen, for it reveals Isaac as a victim to Abraham's role as a priest, and also allows him to "contribute equally with the priesthood itself". Luther does credit Isaac later for his unknowing willingness in that he allows his father to bind him as a butcher would. Isaac at that point, Luther notes, is letting his father perform the priestly duty of the rite of burnt offering. Luther states: "The son is obedient, like a sheep for the slaughter, and he does not open his mouth. With the exception of Christ we have no similar example of obedience". ${ }^{63}$

At the same time, the interpreters notice that all this activity is narrated without a word about Abraham's internal world. For Luther, the very details of Abraham's preparation suggest emotions too great to be described. Luther imagines the father's torment in something otherwise as pedestrian as saddling his donkey. Throughout his reflections on the story, Luther remains acutely sensitive to the psychological drama beneath the detailed description of Abraham's actions. Luther wonders: "should he not have deliberated further in a matter so sad and astonishing?" And further, should he not have asked for his wife Sarah's counsel? Luther asserts that all the emotion lies as it were behind the details, namely, that Abraham is "so absorbed, he barely knows what he's doing". ${ }^{64}$

The scene with all of Abraham's deliberative action and the length of the journey is tense, fraught with unspoken emotion. The narrative is indeed gripping for what it does not say, namely, the emotional hell this father and son must have been going through. When Isaac asks, "behold, the fire and the wood; but where is the lamb for a burnt offering? (verse 7), Jewish interpreters wonder if the son knows what the father is up to. ${ }^{65}$ They debate if Isaac is naïve, sad, obedient too, or frightened. Luther argues that Isaac is obedient, even "solicitous about the glory of God" in asking about the sacrifice, but unknowing about its intended victim. ${ }^{66}$ Indeed, the narrative tension in this story of Abraham's offering remains so high that it has long been considered a masterpiece of the Old Testament, to be sure, and also in the annals of world literature itself. E. Auerbach's seminal study, Mimesis,

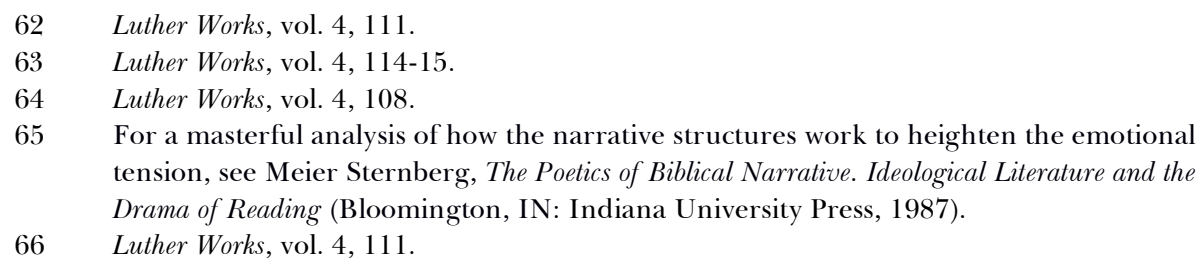


favorably contrasts the aesthetic conventions of this biblical tale with Homer's depiction of Odysseus' homecoming in the Odyssey". ${ }^{67}$ Auerbach argues that the narrative's subjective austerity is what makes the tale so gripping; that Abraham's internal struggle is omitted, with only the external tasks, e.g., walking together, saddling his donkey carrying the wood, etc., provided in its stead.

\section{The Servants and Donkey Remain Behind (verse 5)}

No detail is left unexamined by Christian interpreters in this important tale. In verse 5, Abraham tells his servants to remain behind with the donkey while "I and the lad go yonder and worship, and come again to you". Luther provides spiritual insight from this verse. He advises that we should do as Abraham did: "when we wish to ascend to God, we should come with Isaac alone, that is, with Christ through faith; the servants and ass, that is, our works, we should leave below" ${ }^{68}$ Caesarius of Arles asks why the text has the servants stay "with the donkey" and concludes that the animal is a symbolic of their weak faith. At times, typology could work overtime and try to render hidden meaning from every detail. Caesarius, in this instance at least, might have been better off taking a page from Freud's playbook and acknowledging that sometimes a donkey is just a donkey.

Caesarius of Arles, alas, has a darker supersessionist ${ }^{69}$ reading of the significance of the servants remaining behind with the donkey. The servants, he asserts, represent the Jewish people, and the donkey represents the synagogue. ${ }^{70}$ For Caesarius, it is as if the servants—-the Jews-are guilty by association with the beast of burden. They are, for Caesarius, as stubborn as the donkey they are left with, and Abraham somehow knows that they cannot handle the truth that he is obeying. It is evident from such hostile typoPrinceton University Press, 1974), 3-23. persists in Christian attitudes toward and unfamiliarity with the Old Testament. The Second Vatican Council, in its Dogmatic Constitution on Divine Revelation sought to repair the anti-Semitism and supersessionism by advocating that both Testaments be read for God's saving actions. 
logical exegesis that Caesarius's faith for Christ has slipped into an antiSemitic triumphalism that has proven far more stubborn in Christian history than any donkey.

The interpreters are vexed by the potential deception of Abraham with the servants. Does Abraham lie to his servants by saying that he and his son are off to worship and return? For, he knows that obeying God's command will mean that he returns alone. Origen is convinced that Abraham is not lying to the servants because, following Hebrews 11:19, he believes in the resurrection. ${ }^{71}$ Hence somehow, even if Isaac is slaughtered, Abraham will not return to the servants alone. Luther adds that this is why the two must go alone for the rest of the way, only they know the truth of resurrection. ${ }^{72}$ Caesarius also believes that the patriarch is not lying, but he draws instead on Abraham's own history rather than the verses in Hebrews to make the point. Abraham, he reminds us, believes in a God who gave him a son from a sterile woman, ${ }^{73}$ so he goes into the journey knowing that "nothing is too wondrous for the Lord" (Genesis 18:14).

Augustine too believes that Abraham has not lied to the servants when he tells them to remain behind. His reasoning parallels that of Caesarius in that he draws on Abraham's own personal history rather than the New Testament passage. He reasons against any deception on the patriarch's part:

On the contrary, in his heart there was always the same unshaken and absolutely unfailing faith. Abraham reckoned, you see, that the God who had granted that one who did not exist should be born to aged parents would also be able to restore him from death. What God had already done was much greater-when Abraham saw himself given a son after all hope had faded—was indeed, if you consider the human limitations, impossible. So he gave his mind wholly to faith. He did not believe that anything was impossible to the creator. Having begotten a son by trusting God, he later on trusted God when he gave this order. ${ }^{74}$

Their exegesis of Abraham's guilelessness adds a vital theological realism to Christian interpretation of Abraham's offering. If Abraham obeys God's command to sacrifice his son because he somehow intuits a resurrection that is not revealed until Christ, then he is no doubt admirably precocious. But the nature of his faith is then proleptic - that is, built on the future event in

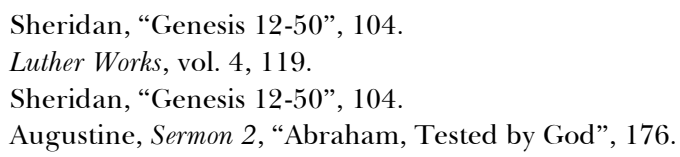


Christ's resurrection, as it was for the author of Hebrews. This notion has the effect of diminishing the actual lived faith of Abraham's personal history. It is akin to the Christian today who believes because of an afterlife in heaven. Abraham is the father of faith because this has been proven over and over again within his life. He emigrated without knowing his destination, performed a new rite of circumcision on himself and all the men of his household (Genesis 17:23-27), and had a son when he was 100 years old and Sarah, who had been barren her entire life, was in her nineties (Genesis $17: 17 ; 21: 5)$. After some initial incredulity, Abraham had faith in this God who had given him Isaac against all odds. ${ }^{75}$ That birth had certainly gone against reason and physiology, so why would his faith not transcend them again? This patriarch had learned through experience that nothing was too wonderful for God.

Once the servants are left behind, father and son walk together for the rest of the journey. Their conversation consists of a terse two verses, verses $7-8$.

So they went both of them together (6b). And Isaac said to his father Abraham, "My Father!" and he said, "Here I am, my son". He said, "Behold, the fire and the wood; but where is the lamb for a burnt offering?" Abraham said, "God will provide himself the lamb for a burnt offering my son". So they went both of them together. verses $6 \mathrm{~b}-8$

I have included the ending of the previous verse, v6b, because the same phrase occurs at the end of verse 8 and so frames the conversation in the scene. The syntactic frame emphasizes that Abraham and Isaac are united. In addition, the conversation begins as the story itself had with one character calling and the other responding with "here I am!" In the Bible, this phrase connotes ready attentiveness, not mere location. Isaac (and God) easily knows where Abraham is.

Isaac shares with his father that he sees all the preparations are intact for a sacrifice except the main element, the victim. Abraham answers only "God will provide the lamb for a burnt offering my son" (verse 8). For Origen, his answer refers to Christ: Abraham is responding to present things with future things. ${ }^{76} \mathrm{He}$ is, Origen clarifies, not lying to Isaac, but trusting in God utterly. Luther too insists that Abraham is not lying to his son, because it is 
true that God will (later) provide it in the form of a ram caught in a thicket. ${ }^{77}$ Abraham's answer also demonstrates a fatherly mercy in not telling Isaac his fate. At the same time, Luther is convinced that the lost transcript of their conversation would have included "no doubt" the doctrine of the resurrection of the dead, which they both knew. ${ }^{78}$ The rabbis, however, notice the ominous juxtaposition of "burnt offering" with "my son" in verse $8 .{ }^{79}$ For them as well, Abraham is also not lying; instead he answers his son with brutal, if uncaught, honesty.

\section{The Substituted Ram}

The story of Abraham's offering has a dual typology of Christ: Isaac, the willing son, and the ram substituted at the last moment. Innocence is thus doubly emphasized. And so Origen maintains that the ram is a type of Christ in flesh, while Isaac is a type of Christ in spirit. ${ }^{80}$ The ram is the substitution offered by an angel of the Lord (verse 13). Many Christian interpreters note the allusion to atonement. The ram caught in a thicket (wood) is like Christ on the cross. ${ }^{81}$ For Ambrose, the ram is the Word "full of tranquility and restraint and patience". ${ }^{82}$ Athanasius adds a theological reason for the substitution as well. He states that there is a delay, a reprieve in the story because the death of Isaac could not buy freedom for the world; only the savior could do so. ${ }^{83}$ The ram caught in a thicket prefigures Christ for Augustine as well. And, it is for him, a nice example of how all the pages of the Old Testament "keep vigil" for the events of Christ's coming. ${ }^{84}$ Here, the ram caught in a thicket heralds that "other Ram", Jesus and his cross. "We can even say that the ram was a symbol of Christ, for to be held fast by the horns is like a crucifixion. So all this obscurely prefigures Christ" ${ }^{85}$

Luther Works, vol. 4, 112.

Luther Works, vol. 4, 113. Such theological talk, though, might have aroused Isaac's suspicions.

H. Freedman, trans., Genesis Rabbah, vol. 1 (London: Soncino, 1939), 494.

Origen, Sheridan, "Genesis 12-50", 109.

Augustine, The ram was a symbol of Christ, for to be held fast by the horns is like a crucifixion, "De Civ Dei 16.32"; "Dei Trin 3.25"; Ephrem the Syrian, the ram in the tree represents Christ on the cross FC 91:169; Sheridan, "Genesis 12-50", 104.

Ambrose, FC 26:115-16.

Sheridan, "Genesis 12-50", 110.

Augustine, In His Own Words, 227.

Ibid., 342 .

PERICHORESIS 10.1 (2012) 
Chrysostom calls the thicket a type of cross, so that Abraham witnesses the truth of Christ in shadow, long before. ${ }^{86}$

Luther draws a parallel with Christ's two natures here. Isaac stands as Christ's divine nature, which does not die, while in the ram "here Christ, the Son of God, is prefigured, who like a mortal man died on the cross. Yet the divine nature did not die, the human nature being sacrificed in its place" ${ }^{87}$ Modern biblical scholars, by way of contrast, consider the substitution to reflect a cultural transition in ancient Israel from human to animal sacrifice. ${ }^{88}$ The etiological view does not fully explain why there is no condemnation in the narrative itself about the divine command. ${ }^{89}$

\section{"Now I Know" (verse 12)}

After twelve verses fraught with dramatic tension, the angel of the Lord intervenes and the ordeal ends (verse 12). In the Bible, angels are simply messengers from God who otherwise look entirely ordinary, except for their sudden appearance. From the Hebrew malak, meaning "messenger" or "angel", they appear at crucial times in biblical narratives and serve as, what Karl Barth termed, "the ambassadors of God". ${ }^{00}$ They are not the winged, chubby babies of Renaissance art. Barth reminds us that divine presence in the Bible is never harmless and sentimental, but is formidable, and usually life-changing. ${ }^{91}$

The angel of the Lord says to Abraham, "Now I know" that you fear God (verse 12). Christian interpreters are bothered by the adverb "Now" since it might well suggest that the Lord and his angel did not previously know something. They want at all times to preserve God's omniscience. Origen says that the adverb is added in verse 12 for our sake, as a way to highlight that Abraham has clearly passed the test. He adds too that "now" there is also a certainty in Abraham's inner heart; he knows for sure that he is fully obedient to his God, regardless of the command. "Now" is written to guide spiritual hearers of the tale with their own discernment and to con-

86 Sheridan, "Genesis 12-50", 110.

87 Luther, Martin. "Sermons on Gospel Texts for Advent, Christmas, and Epiphany", vol. 1, Sermons of Martin Luther, 284.

88 Jon D. Levenson, The Death and Resurrection of the Beloved Son, 112-14; Gunkel, 233-40.

89 Konrad Schmid, “Abraham's Sacrifice: Gerhard von Rad's Interpretation of Genesis 22”, Interpretation 62 (2008), 269; Levenson, 113.

90 Karl Barth, Church Dogmatics, vol. 3, pt 3 (Edinburgh: T. \& T. Clark, 1936), 477.

91 Barth, Church Dogmatics, 489.

92 Sheridan, “Genesis 12-50", 107-08. 
firm the peace of unconditional faith within Abraham. Augustine follows suit: "You must know then, dearly beloved, that God's testing is not aimed at his getting to know something he was ignorant of before, but at bringing to light what was hidden in a person ... People are not as well known to themselves as they are to their creator... ${ }^{93}$

Aquinas is also quick to affirm God's omniscience in the tale. He interprets the phrase "Now I know" in verse 12 with the use of an analogy with Christ's own knowledge:

The meaning is not that He who knows all things from eternity began to know at that moment, but that He made known Abraham's devotedness by that declaration. In a similar way the Son is said to be ignorant of the day of judgment, because He did not impart that knowledge to the disciples, but replied to them, Acts 1:7: "It is not for you to know the times or moments which the Father hath put in His own power. ${ }^{94}$

God (and Christ) knows all things, but we his disciples come to understanding in divine mysteries. Here, then, God makes "known Abraham's devotedness" so that we too can "now" grow in our own devotedness to the Lord. Aquinas sees a patient, nuanced pedagogy always at work in God's revelation in Holy Scriptures.

Luther's tack is somewhat different as he seeks to defend Abraham rather than God in his discussion of the adverb "now" in verse 12. Abraham, he says, "was previously good and obedient". What transpires in his offering of Isaac is that the inner state of Abraham is manifest outwardly, i.e., it is revealed. The difference is important for Luther because Abraham is an exemplar of faith: "He does not say: Now you have become Godfearing; but by this work it is revealed and made known that you fear God". "Now" for Luther is a grammatical marker signaling a revelation, a manifestation of something-Abraham's faith-that was always there. He continues on a philosophical bent,

93 Augustine, "Sermon 2, Abraham Tested by God", 177.

94 Aquinas, "Compendium on Theology", in The Collected Works of St. Thomas Aquinas, 300. 
Hence these are two distinct things, to be or become something, and that something be made known or revealed. There are many things that are known to God alone, but when it is revealed it also becomes known to man. ${ }^{95}$

\section{The Fear of God}

The angel of the Lord intervened to stay Abraham's hand from killing his son (verse 12). We learn at that point that Abraham has passed the test, as Abraham clearly "fears God". This phrase, a biblical trope, deserves some comment. The "fear of God" denotes a posture of reverence and awe toward the holy, more than it does outright fright. It describes an attitude of humility in God's presence and so is often used in scenes of worship or supplication. When the book of Proverbs begins "The fear of the Lord is the beginning of wisdom" (Proverbs 1:7), the author summons the humble posture typical of worship for study of life's ways. ${ }^{96}$ Abraham has amply demonstrated that he reveres the Lord since he has the knife lifted to slay his son.

The concluding verses, 15-19, as we noted above, are a repetition of the promise made to Abraham earlier (Genesis 12:2-3, 15:5-6, 17:4-8). Therefore, they cannot be a reward for Abraham's ready display of obedience in offering his son. Origen understands the repetition of the promise as a confirmation "of faith" what was before bestowed "of flesh", at the rite of circumcision (Genesis 17:4-8). He notices an added detail in verse 15 that the promise is "from heaven", whereas earlier it had been "from earth". ${ }^{97}$ By and large, Christian interpreters do not spend much time on these concluding verses and view their overall effect as confirmation of God's promises.

Augustine is the notable exception. Isaac is a type of Christ, and the repeated promise of many descendents is a prefiguring of Christ's many followers, i.e., the church. The angel says to Abraham,

Because you have done this, and have not withheld your loved son, I will bless you and I will multiply your descendents as the stars of heaven ... and by your descendents shall all the nations of the earth be blessed. verses 16-18 Trinity, vol. 4 of Sermons of Martin Luther, 278-279.

96 Westermann, "Genesis 12-36". The notion of the "fear of God" in found primarily in three traditions, Deuteronomy, Psalms, and Wisdom. Source theory considers the phrase in narrative to be $\mathrm{E}$, the Elohist. 
With "son" as Christ and "descendents" his church, Augustine offers an ecclesiological reading of the promise: "no sooner had the Head been foretold than the body must be too". These verses do not merely repeat an earlier promise. They bear new revelations from God about the church. Augustine continues on these verses: "The Spirit of God began-God himself began-to want to preach to Abraham about the Church, and to do so he discarded figurative language. He proclaimed Christ in a figurative way but foretold the Church quite openly". That is, whereas Christ was figuratively present as Isaac in the story of Abraham's offering, the church is directly indicated in this reiterated promise of descendents. Augustine's exegesis accounts for the seeming repetition; it contains new revelation. The promise to Abraham has always involved a multitude of descendents through Isaac. But after his near sacrifice as a Christ figure, the multitude is the church which emerged after Christ's death and resurrection.

\section{Conclusion}

In conclusion, Christian interpreters have demonstrated a careful, theologically nuanced exegesis of the story of Abraham's offering. They have sought to draw out connections between God and Abraham as father, and Christ and Isaac as son. As a result, they enable us to reflect more deeply on the tensions between faith, obedience, and love in Christian life. It is clear from their steadied exegesis that Abraham's offering is not at all about blind faith or blind obedience. Abraham and Jesus as well take their long, gritty journey in a faith that is arduous. The biblical meaning of faith is trust. Abraham is deservedly the father of faith because he trusted God throughout the journey to Mount Moriah. His was a faith that was never simplistic or robotic. With his beloved son on the line, it could not afford to be.

The Christian interpreters, because they are confessional, know something that perhaps we sometimes forget, namely, that faith is painstaking, contradictory, and really difficult to maintain. They understand Abraham to be an example for Christian faith not because he never waivers, but in watching closely how he does not. Their typological forays were never intended as literary whimsy, interpretation for its own sake or for the sake of cleverness. They were motivated by a homiletic desire to make the God in this story known as the same God of Jesus Christ. They viewed scripture, both Testaments, as a unity that revealed God's nature and contained spiritual instruction. The lessons Abraham learned, since timeless and divine, were lessons that Christian followers could learn right alongside him. His 
willingness to put nothing, no one, before God is the theological lodestar of the story.

It is true that Christian interpreters saw the good news in the story in part because they went looking for it through typology. But it is also true that they found the goodness in the details themselves. There was in the end no horrific killing because the God who led Abraham his entire life was leading him still through this his worst ordeal. And that consistent, dependable, providential God is the same God leading Jesus and all of us through our ordeals. "Faith", as Barth says, "is holding, in spite of all that contradicts it, once for all, exclusively and entirely to God's promise and guidance". ${ }^{98}$ The Christian interpreters probe beyond the idea that obedience is pleasing to God. It is certainly that as the angel of God let Abraham know. Abraham's obedience, they notice, enables God to take him to a new level, past the point where death stings. Luther makes this distinction:

Natural death, which is the separation of the soul from the body, is simple death. But to feel death, that is, the terror and fear of death-this is indeed real death. Without fear death is not death; it is a sleep, as Christ says (John 11:26). ${ }^{99}$

Abraham, by his obedience, glimpsed death from God's perspective and was thus freed from fear of it. Christians who truly understand the resurrection share precisely this freedom with Abraham.

\section{Bibliography}

Ackroyd, P. R., and C. F. Evans, eds. The Cambridge History of the Bible. From the Beginnings to Jerome. Cambridge: Cambridge University Press, 1970.

Aquinas, Thomas. The Collected Works of St. Thomas Aquinas. Electronic edi-

tion. Charlottesville, VA: InteLex Corporation, 1993. http://pastmasters2000.nlx.com.ezp1.villanova.edu/xtf/view?dcId=aquinas/aquinas.00. $\mathrm{xml}$;chunk.id=div.aquinas.pmpreface. 1 ; toc.depth $=1 ;$ toc.id $=$ div.aquinas .pmpreface. 1 ; brand $=$ default\&fragment_id $=$

Auerbach, Erich A. Mimesis. The Representation of Reality in Western Literature.

Translated by Willard R. Trask. Princeton, NJ: Princeton University Press, 1953. 
Augustine, St. The Works of Saint Augustine (3rd release). Electronic edition. Charlottesville, VA: InteLex Corporation, 2001. http://pastmasters2000.nlx.com.ezp1.villanova.edu/xtf/view?docId=augustine_iii/augustine _iii.00.xml;chunk.id=div.aug.pmpreface. 1 ;toc.depth $=1$; toc.id $=$ div.aug. pmpreface. 1 ;brand $=$ default\&fragment_id $=$

Bailie, Gil. Violence Unveiled. Humanity at the Crossroads. New York, NY: Crossroads 1997.

Barth, Karl. Church Dogmatics, vol. 3, pt 3. Edinburgh: T\&T Clark, 1936. Dogmatics in Outline. New York, NY: Harper, 1959.

Calvin, John. Institutes of the Christian Religion. Translated by Henry Beveridge. Grand Rapids, MI : Eerdmans, 1953.

Finlan, Stephen. Problems with Atonement. The Origins of, and Controversy about, the Atonement Doctrine. Collegeville, MN: Liturgical, 2005.

Flannery, Austin. O. P, ed. "Dogmatic Constitution on Divine Revelation". Vatican Council II. Vol. 1: "The Conciliar and Postconciliar Documents". Northport, NY: Costello, 1975.

Freedman, H. trans. Genesis Rabbah. Vol. 1. London: Soncino, 1939.

Gunkel, Hermann. Genesis. Translated by Mark E. Biddle. Macon, GA: Mercer University Press, 1997.

Harmless, William, S.J., ed. Augustine in His Own Words. Washington, DC: Catholic University of America Press, 2010.

Howard, C. T. R., trans. Saint Jerome's Hebrew Questions on Genesis. Oxford: Clarendon, 1995.

Jensen, Robin M. "The Binding or Sacrifice of Isaac: How Jews and Christians See Differently". Bible Review 9 (1993): 42-51.

Johnson, Luke Timothy. The Writings of the New Testament. An Interpretation. Minneapolis, MN: Fortress Press, 1999.

Lampe, G. W. H., ed. The Cambridge History of the Bible. The West from the Fathers to the Reformation. Cambridge: Cambridge University Press, 1969.

Lerch, D. Isaaks. Opferung Christlich Gedeutet. Tübingen: Verlag, J. C. B. Mohr, 1950.

Levenson, Jon D. The Death and Resurrection of the Beloved Son. The Transformation of Child Sacrifice in Judaism and Christianity. New Haven, CT: Yale University Press, 1993.

Luther, Martin. "Sermons on Gospel Texts for Advent, Christmas, and Epiphany". Volume 1. Sermons of Martin Luther. Electronic edition. Charlottesville, VA: InteLex Corporation, 1995. http://pastmasters2000.nlx.com.ezp1.villanova.edu/xtf/view?dcId=luther/luther.00.xml;chunk.id=d 
iv.luther.pmpreface. 1 ; toc.depth $=1$;toc.id = div.luther.pmpreface. 1 ;brand $=$ default\&fragment_id $=$

Luther, Martin. "Sermons on Gospel Texts for the 1st to the 12th Sundays afterTrinity". Volume 4. Sermons of Martin Luther. Electronic edition. Charlottesville, VA: InteLex Corporation, 1995. http://pastmasters2000.nlx.com.ezp1.villanova.edu/xtf/view?dcId=luther/luther.00.xml;chunk.i $\mathrm{d}=$ div.luther.pmpreface. $1 ;$ toc.depth $=1 ;$ toc.id $=$ div.luther.pmpreface. $1 ; \mathrm{b}$ rand $=$ default\&fragment_id $=$

Moberley, R. W. L. "The Earliest Commentary on the Akedah". Vetus Testamentum 38 (1988): 302-23.

Moltmann, Jurgen. The Crucified God. The Cross of Christ as the Foundation and Criticism of Christian Theology. Minneapolis, MN: Augsburg Fortress, 1993.

Pelikan, Jaroslav, ed. Luther's Works. Vols. 4, 7-8. St. Louis, MO: Concordia, 1964.

Noort, Ed and Eihert Tigchelaar, eds. The Sacrifice of Isaac. The Aqedah (Genesis 22) and its Interpretations. Leiden: Brill, 2002.

von Rad, Gerhard. Genesis. A Commentary. Translated by John H. Marks. London: SCM, 1972.

Schmid, Konrad. “Abraham's Sacrifice: Gerhard von Rad's Interpretation of Genesis 22". Interpretation 62 (2008): 268-76.

Schopp, Ludwig, et al. eds. The Fathers of the Church. A New Translation. Washington, DC: Catholic University of America Press, 1947.

Schwartz, Regina M. The Curse of Cain. The Violent Legacy of Monotheism. Chicago, IL: University of Chicago Press, 1997.

Sheridan, Mark, ed. Genesis 12-50. Vol. 2. Ancient Christian Commentary on Scripture. Old Testament. IVP Academic, 2002.

Spiegel, Shalom. The Last Trial. Translated by Judah Goldin. New York, NY: Random House, 1967.

Steinmetz, David C. "The Superiority of Pre-Critical Exegesis", Theology Today 37 (1980): 27-38.

Sternberg, Meier. The Poetics of Biblical Narrative. Ideological Literature and the Drama of Reading. Bloomington, IN: Indiana University Press, 1987.

Westermann, Claus. Genesis 12-36. A Commentary. Translated by John J. Scullion. Minneapolis, MN: Augsburg, 1985. 